\title{
IMPACT OF ADENOTONSILLECTOMY ON BRONCHIAL ASTHMA IN CHILDREN
}

\author{
By
Mahmoud Mohammed Ramadan Khaleel ${ }^{1 *}$, Mostafa Mohammed El- Sayed $^{1}$, Yahia Mohammed Dawood ${ }^{1}$ and Abd El-Sattar Abdullah El- Sayeh $^{2}$ \\ ${ }^{1}$ Departments of Otorhinolaryngology and ${ }^{2}$ Pediatrics, Faculty of Medicine, Al-Azhar \\ University
}

E-mail: doctormahmoud1989@gmail.com

\begin{abstract}
Background: Asthma is a heterogeneous disease, usually characterized by chronic airway inflammation. It is defined by the history of respiratory symptoms such as wheeze, shortness of breath, chest tightness and cough that vary over time and in intensity, together with variable expiratory airflow limitation.
\end{abstract}

Objective: To detect the impact of adenotonsillectomy operation on control of bronchial asthma in pediatric population based on clinical assessment of preoperative and postoperative asthma symptoms control.

Patients and Methods: This was a prospective case series study of 40 patients with chronic adenotonsillitis and bronchial asthma. The patients to be studied were recruited from the outpatient clinic of Otorhinolaryngology Department, Al-Hussein University Hospital during the period from January 2020 till April 2020. The patients were evaluated pre-operatively regarding asthma status using Childhood Asthma Control Test, and measuring peak expiratory flow rate. Adenotonsillectomy operation was done for them, and 3 months post-operatively, asthma was re-evaluated using the same previous methods.

Results: There was a highly significant difference between preoperative and postoperative condition regarding Childhood Asthma Control Test results and peak expiratory flow rate which was in favor of overall improvement of asthma control.

Conclusion: Adenotonsillectomy in asthmatic patients with chronic adenotonsillitis led to significant improvement in asthma symptoms control and most of the patients were able to improve their life style.

Keywords: Adenotonsillectomy - Bronchial Asthma - life style improvement.

\section{INTRODUCTION}

Tonsillectomy is one of the most commonly performed surgical procedures. Two common reasons for this surgery are sleep-disordered breathing (SDB) and recurrent throat infections. Several complications are documented with tonsillectomy and include bleeding, velopharyngeal insufficiency and dehydration. According to the American Academy of Otolaryngology-Head and
Neck Surgery, the definition of tonsillectomy is a "surgical procedure performed with or without adenoidectomy that completely removes the tonsil, including its capsule, by dissecting the peritonsillar space between the tonsil capsule and the muscular wall. Depending on the context in which it is used, it may indicate tonsillectomy with adenoidectomy, especially in relation to SDB (Baugh et al., 2011). 
Bronchial asthma is a heterogeneous pulmonary disorder characterized by recurrent episodes of cough, breathlessness and wheezing which may resolve spontaneously or after the use of bronchodilator medications (Agarwal et al, 2015).

This study aimed to detect the impact of adenotonsillectomy operation on control of bronchial asthma in pediatric population based on clinical assessment of preoperative and postoperative asthma symptoms control.

\section{PATIENTS AND METHODS}

This was a prospective case series study of 40 patients with chronic adenotonsillitis and bronchial asthma. Patients were recruited from the outpatient clinic of Otorhinolaryngology department, Al-Hussein University Hospital during the period from January 2020 till April 2020. The patients were evaluated preoperatively regarding asthma status using Childhood Asthma Control Test and measuring peak expiratory flow rate. Adenotonsillectomy operation was done for them and 3 months post-operatively; asthma was re-evaluated using the same previous methods.

\section{Inclusion Criteria:}

1. Children, (four to eleven years old).

2. Clinical diagnosis of chronic adenotonsillitis.

3. Clinical diagnosis of bronchial asthma.

\section{Exclusion criteria:}

1. Proven bleeding tendencies as hemophilia or purpura.
2. Craniofacial abnormalities (e.g. cleft palate).

3. Associated cardiac disease.

All Patients had been subjected to full history taking and full examination. Current asthma control status was recorded using the Childhood Asthma Control Test (cACT) regarding the past 3 months prior to adenotonsillectomy operation. Pulmonary function test, peak expiratory flow rate (PEFR), was implented as an objective method to give an idea about air way resistance during expiration in co-operative children. Routine preoperative laboratory investigations included complete blood picture, prothrombin time and concentration, and bleeding and clotting time.

All patients underwent adenotonsillectomy operation at AlHussein University Hospital, Otorhinolaryngology Department after taking written consent from the child's caregiver. Under GA, administered via an oral endotracheal tube (ET), Adenotonsillectomy was done using cold dissection technique; being the commonest method of tonsillectomy, as well as it is safer and more favorable than the bipolar electrocautery technique (Forod et al., 2017).

Postoperatively, patients who underwent adenotonsillectomy were monitored carefully with a view to early detection of any hemorrhage. This involved regular measurements of pulse rate and observation for excessive swallowing or any frank bleeding from mouth or nose. Asthma controller medications were continued, and then 
stopped gradually according to the follow up with the pediatric pulmonologist.

Three months after doing the adenotonsillectomy operation, patients were re-assessed using the asthma control survey to re-evaluate the current asthma condition. Follow up period was continued up to 3 months as this is the half-life of most of mediators of bronchial asthma reactions (Borish et al 2001).

Assessment of asthma control in this study was according to childhood asthma control test (cACT) and PEFR. Childhood Asthma Control Test was for children 4 to 11 years old. This test provided a score that may help the doctor determine if the child's asthma treatment plan was working or if it might be time for a change (Liu et al., 2010).

\section{Statistical analysis:}

Recorded data were analyzed using the statistical package for the social sciences, version 20.0 (SPSS Inc., Chicago, Illinois, USA). Quantitative data were expressed as mean \pm standard deviation (SD). Qualitative data were expressed as frequency and percentage.

- Paired sample t-test of significance was used when comparing between related samples.

- Chi-square $\left(\chi^{2}\right)$ test of significance was used in order to compare proportions between qualitative parameters.

- The confidence interval was set to 95\% and the margin of error accepted was set to $5 \%$. So, $\mathrm{P}$-value $\leq 0.05$ was considered significant.

\section{RESULTS}

There was a statistically significant improvement in postoperative score compared to preoperative score regarding number of patients improved according to childhood asthma control test (Table 1).

Table (1): Comparison between Preoperative score and Postoperative score regarding number of patients improved according to Childhood asthma control test

\begin{tabular}{|c|c|c|c|}
\hline Childhood asthma control test & $\begin{array}{c}\text { Preoperative } \\
\text { score(number } \\
\text { of patients) }\end{array}$ & $\begin{array}{c}\text { Postoperative } \\
\text { score(number } \\
\text { of patients) }\end{array}$ & p-value \\
\hline Not Controlled<19 & $40(100 \%)$ & $8(20 \%)$ & \multirow{3}{*}{$<0.001$} \\
\hline Controlled >19 & $0(0 \%)$ & $32(80 \%)$ & \\
\hline Total & $40(100 \%)$ & $40(100 \%)$ & \\
\hline
\end{tabular}


There was a statistically significant increase mean of postoperative score compared to preoperative score according to childhood asthma control test (Table 2).

Table (2): Comparison between Preoperative score and Postoperative score according to Childhood asthma control test

\begin{tabular}{|c|c|c|c|}
\hline & Childhood asthma control test & & \multirow{2}{*}{ p-value } \\
Score & Range & Mean \pm SD & \multirow{2}{*}{$<0.001$} \\
\hline Preoperative score & $4-19$ & $14.40 \pm 3.30$ & \\
\hline Postoperative score & $13-27$ & $22.60 \pm 4.17$ & \\
\hline
\end{tabular}

There was a statistically significant increase mean of postoperative score compared to preoperative score according to peak flow meter (Table 3).

Table (3): Comparison between Preoperative score and Postoperative score according to Peak flow meter

\begin{tabular}{|c|c|c|c|c|}
\hline Reak flow meter $(\mathbf{L} / \mathbf{m i n})$ & $\begin{array}{c}\text { \% of } \\
\text { patient's } \\
\text { best }\end{array}$ & $\begin{array}{c}\text { Range } \\
(\mathbf{L} / \mathbf{m i n})\end{array}$ & Mean \pm SD & p-value \\
\hline Score & $46-74 \%$ & $60-136$ & $90.75 \pm 22.40$ & \multirow{2}{*}{$<0.001$} \\
\hline Preoperative score & $53-94 \%$ & $73-297$ & $145.80 \pm 55.53$ & \\
\hline
\end{tabular}

\section{DISCUSSION}

Controversy in literature whether adentonsillectomy (ATE) has a beneficial effect in controlling manifestations of bronchial asthma in children or not had been noticed. Thus, clarifying the nature of the relationship between ATE and control of asthma through a prospective study was of a great importance and would have therapeutic implication.

In this current prospective case series study, we aimed to detect the impact of adentonsillectomy (ATE) operation on the control of bronchial asthma in pediatric population who suffered both chronic adenotonsillitis and bronchial asthma. Forty patients were included in our study after applying inclusion and exclusion criteria.
All patients were assessed for the level of asthma control just before performing ATE operation using the childhood asthma control test, and they were reevaluated 3 months later for detection of changes in asthma control level using the same questionnaire. We used such method of assessment of asthma control being one of the most recent and most accepted by asthma clinicians (Liu et al., 2010). In the current study, we implemented the pulmonary function test peak flowmetry as a method of objective evaluation in cooperative children to give an idea about airway resistance pre and 3 months post operatively in term of peak expiratory flow rate.

The heights of tested children were measured as a linear correlation between peak expiratory flow rate and both age 
and height was seen (Radziavicius et al., 2010).

Patients were distributed between different regions in Cairo and Giza. There was a significant improvement of asthma control test results comparing preoperative and postoperative state.

The current study included $70 \%$ of males and $30 \%$ of females. There was a significant improvement in both sexes regarding asthma control test results comparing preoperative and postoperative state. On the other hand, there was a nonsignificant difference between male and female gender regarding such improvement after ATE. This was in agreement with Behl et al. (2010). They explained their results of male predominance to be related to a greater degree of bronchial lability in males. Also, Anuradha et al. (2011) studied the epidemiology of bronchial asthma and found the same conclusion. On the other hand, Kynyk et al. (2011) studied the sex difference and Asthma and found that there was an increased incidence of asthma in females. Data demonstrated that asthmatic females had a poorer quality of life and increased utilization of healthcare compared to their male counterparts despite similar medical treatment and baseline pulmonary function.

The age of the selected cases ranged between 4 and 10 years. There was a significant improvement in them regarding childhood asthma control test results and peak expiratory flow rate comparing preoperative and postoperative state.

This matches the results reported by Busino et al. (2010). Outcome measures of asthma control were analyzed one year preoperatively and one year postoperatively. There was a statistically significant improvement in postoperative asthma severity in all measures including mean hospital visits, systemic steroid administration, asthma medication use, and childhood asthma control test scores.

Another study by Piessens et al. (2012) compared the use of respiratory medication 12 months before and 12 months after ATE. The use of respiratory medications significantly decreased with $32 \%$ in the year after surgery. Bhattacharjee et al. (2014) compared asthma outcomes during 1 year preceding ATE to those during 1 year following ATE. They found that ATE was associated with significant reductions in acute asthma exacerbation (AAE), acute status asthmaticus (ASA) and the frequency of asthma-related emergency room visits (ARERs). Furthermore, ATE was associated with significant reductions in most asthma prescription refills including inhaled corticosteroids, bronchodilators, systemic corticosteroids and leukotriene receptor antagonists.

In contrast to these results, Ceran et al. (2004) found a statistically significant association between frequent tonsillitis and consequent tonsillar hyperplasia with the development of asthma. They suggested that recurrent tonsillitis was associated with a decline in the prevalence of asthma by inducing a T-helper 1 (TH 1) predominant immune response which was compatible with the hygiene hypothesis. This controversy could be explained by the difference in the targeted patients and assessment protocol. 


\section{CONCLUSION}

Adenotonsillectomy in children with bronchial asthma and chronic adenotonsillitis led to significant improvement in asthma symptoms control and most of the patients are able to improve their life style. Earlier adenotonsillectomy before school age in asthmatic children with chronic adenotonsillitis may help to improve asthma control.

\section{REFERENCES}

1. Agarwal R, Dhooria $\mathrm{S}$, Aggarwal AN, Maturu VN, Sehgal IS, Muthu $V$ and Prasad KT (2015): Guidelines for diagnosis and management of bronchial asthma. Lung India., 32(Suppl 1):S3-S42.

2. Anuradha AV, Kalpana $L$ and Narsingarao S (2011): Epidemiological study on bronchial asthma. Indian J Allergy Asthma Immunol., 3(12): 434-6.

3. Baugh RF, Archer SM, Mitchell RB, Rosenfeld RM, Amin R, Burns JJ, Darrow DH, Giordano T, Litman RS, Li KK, Mannix ME, Schwartz RH, Setzen G, Wald ER, Wall E, Sandberg G and Patel MM (2011): American Academy of Otolaryngology-Head and Neck Surgery Foundation. Clinical practice guideline: tonsillectomy in children. Otolaryngol Head Neck Surg., 144(1 Suppl):S1-30.

4. Behl RK, Kashyap S and Sarkar M (2010): Prevalence of bronchial asthma in school children of 6-13 years of age in Shimla city. Indian J Chest Dis Allied Sci., 52(3): 145-8.

5. Bhattacharjee R, Choi BH and Gozal D (2014): Association of adenotonsillectomy with asthma outcomes in children: A longitudinal database analysis. PLoS Med., 11(11): 1001753.

6. Borish LC, Nelson HS, Corren J, Bensch G, Busse WW, Whitmore JB and Agosti JM (2001): Efficacy of soluble IL-4 receptor for the treatment of adults with asthma. Journal of Allergy and Clinical Immunology., 107(6): 963-970.
7. Busino RS, Quraishi HA, Aguila HA, Montalvo E and Connelly P (2010): The impact of adenotonsillectomy on asthma in children. Laryngoscope., 120 (4): S221-28.

8. Ceran O1, Aka S, Oztemel D, Uyanik B and Ozkozaci $T$ (2004): The relationship of tonsillar hyperplasia and asthma in a group of asthmatic children. International Journal of Pediatric Otorhinolaryngology., 68(6): 775778.

9. Forod S, Mohammad R, Mehran H, Mahsa $\mathrm{H}$, Seddigheh $\mathrm{M}$ and Mohammadmehdi $\mathrm{H}$ (2017): Postoperative Outcomes in Cold Dissection Versus Bipolar Electrocautery Tonsillectomy: A Randomized Double-Blind Controlled Study. Indian Journal of Otolaryngology and Head \& Neck Surgery., 71: 182-187.

10. Kynyk JA, Mastronarde JG and McCallister JW. (2011): Asthma, the sex difference. Current Opinion in Pulmonary Medicine., 17(1): 6-11.

11. Liu AH, Zeiger RS, Sorkness CA, Ostrom NK, Chipps BE and Rosa K (2010): The Childhood Asthma Control Test: retrospective determination and clinical validation of a cut point to identify children with very poorly controlled asthma. J Allergy Clin Immunol., 126(2): 267-273.

12. Piessens $P$, Hens G, Lemkens N, Schrooten W, Debruyne $F$ and Lemkens $P$ (2012): Effect of adenotonsillectomy on the use of respiratory medication International Journal of Pediatric Otorhinolaryngology., 76 (6): 906910.

13. Radziavicius FR, Martins LC, Radziavicius CC, Valenti VE, Siqueira AA, de Souza CG and de Abreu LC (2010): Peak expiratory flow values are higher in older and taller healthy male children: an observational study. Clinical and Investigative Medicine., 1: E928 . 
در اسة تأثثر عملية إستثُصال اللوزتين و اللحمية على مرض الأل الربو الثعبي عند الأطفال

محمود محمد رمضان خليل1، مصطفى محمد السيد1، يحيى محمد داود1، عبد الستار عبد الله السايح2 1قسمي الأنن و الأنف و الحنجرة و ططب الأطفال، كلية الطب، جامعة الأزهر

E-mail: doctormahmoud1989@gmail.com

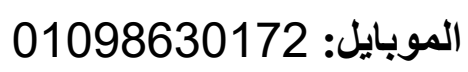

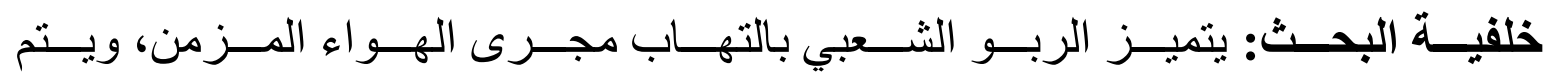

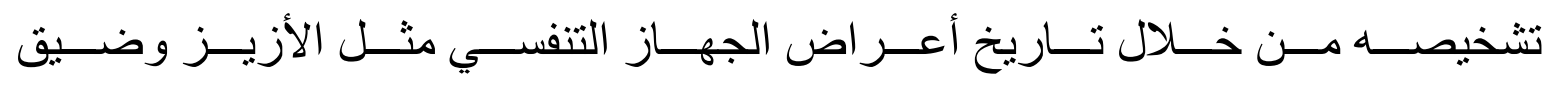

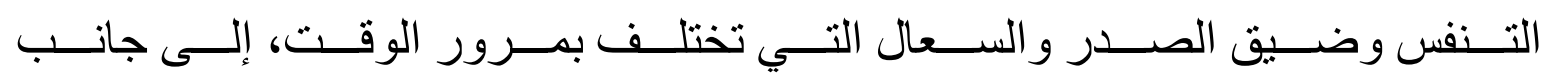

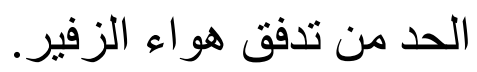

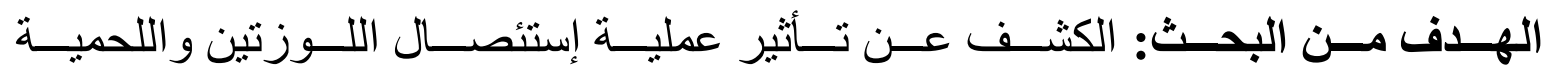

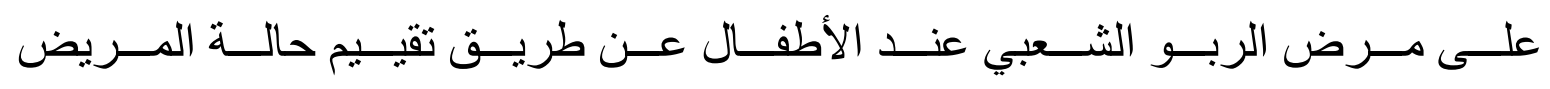
بعد إجر اء العملية ومقارنتها بما قبل إجر اءها.

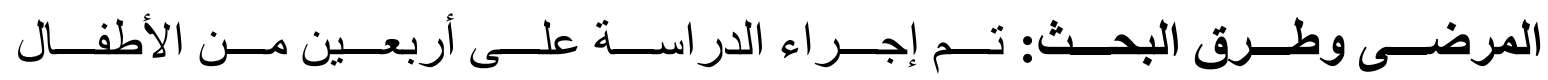

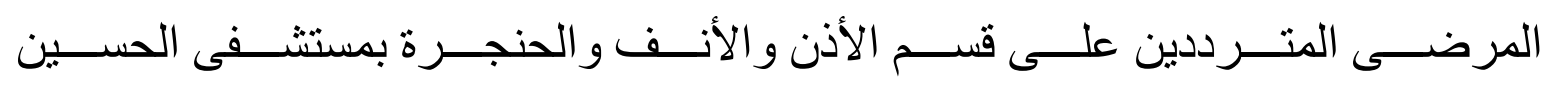

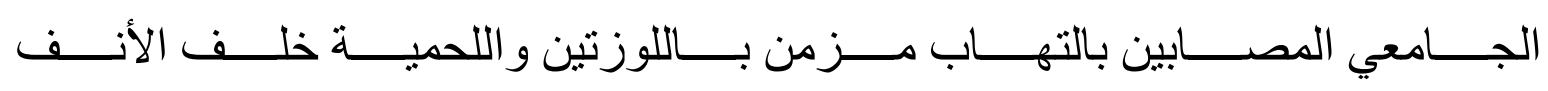

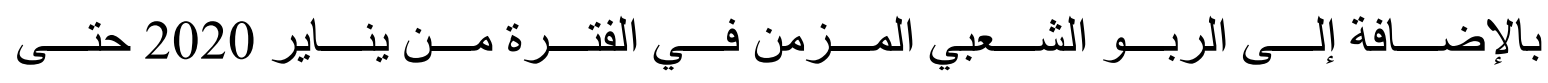

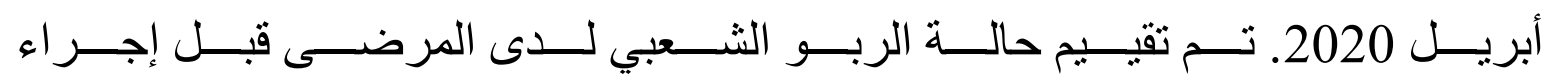

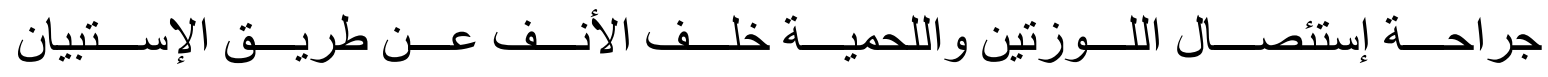

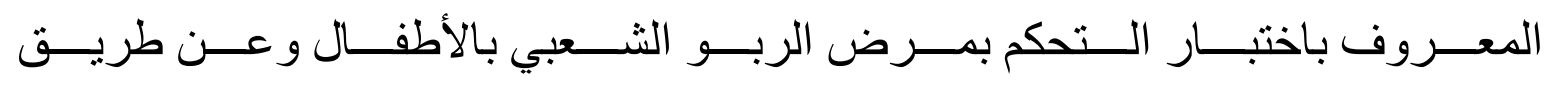

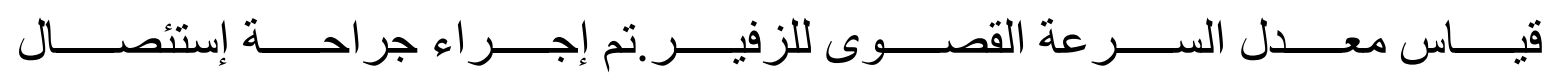

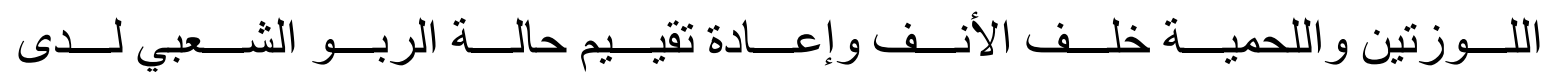




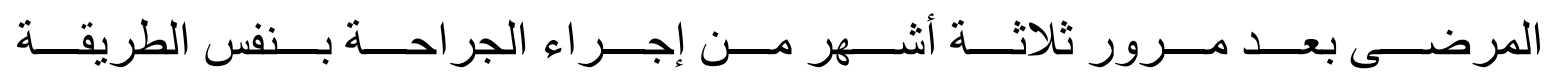
السابقة.

نتــائج البحــث: كــان هنــاك تحســناً عامــاً فــي الـــحكم بـــرض الربــو الثــعبي عند الأطفال بعد إجر اء إستئصال اللوزنين و اللحمية مقارنة بما قبلها.

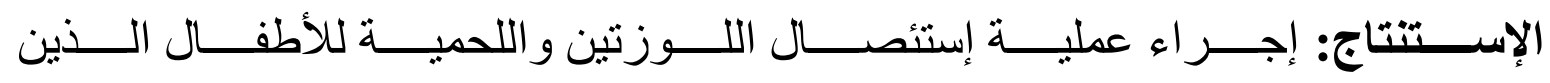

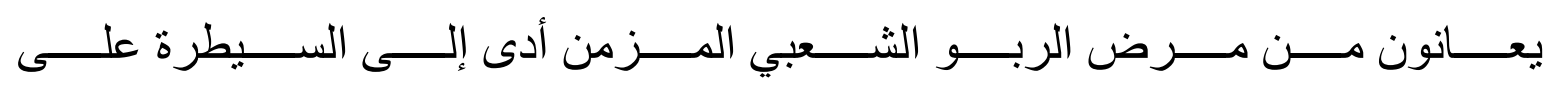

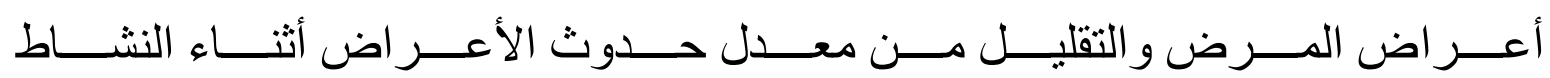

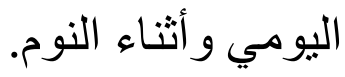

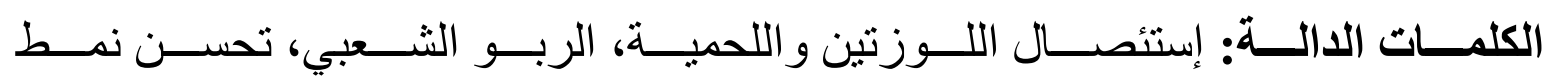
الحياة. 